\title{
IMPROVING THE TENTH-YEAR STUDENTS' WRITING ABILITY AT MA MAMBAUS SHOLIHIN GRESIK THROUGH MIND MAPPING
}

\author{
M. Zaini Miftah
}

Email: miftahzen@yahoo.com

MA Mambaus Sholihin Gresik and is now an English lecturer of STAIN Palangka Raya

Alamat Korepondensi: Jalan G. Obos Komplek Islamic Centre Palangka Raya Kalteng 73112

\begin{abstract}
This study is aimed at developing mind mapping strategy to improve the tenth-year students' writing ability at Madrasah Aliyah (MA) Mambaus Sholihin Gresik and focused on solving the problem of how the students generate and organize ideas for writing a topic. The design of the study is collaborative classroom action research. Both the researcher and his collaborator work together in cyclic activities - planning, implementing, observing and reflecting on the data gained from the teaching and learning process - which runs into three cycles, each of which covers four meetings. The findings show that by implementing mind mapping with the proper model developed, the students' ability in writing a descriptive text improves. It is indicated by the improvement of the percentage of the students achieving the score greater than or equal to 65 and of the percentage of the students' involvement in the writing activities during the implementation of mind mapping in the instructional process in Cycle I, II, and III. The improvement of the students' ability in writing a descriptive text can be reached but it should follow the proced ures of the proper model of mind mapping developed.
\end{abstract}

\section{Keywords}

Mind Mapping, Writing Ability

\section{Introduction}

English as an international language is considered to be the first foreign language in Indonesia (Rachmadie, 1995). In the Indonesian educational system, English becomes a compulsory subject at junior and senior high schools, while it is only as a local-content subject at elementary and university level.

Based on the 2004 English Curriculum, the objective of the English teaching in Indonesia is intended to enable students to use English as a means of communication to access information in daily context, to develop interpersonal relationship, to broaden their knowledge, and to enjoy language esthetics in English culture (Depdiknas, 2003). This statement is parallel with the goal of teaching English in Indonesia as stated in the 2006 Standard of Content that the objective of the English teaching at SMA/MA is directed to develop the four English skills listening, speaking, reading, and writing - in order that the graduates are able to communicate and understand a discourse in an informational literacy stage (Depdiknas, 2006). The graduates are expected to be able to access knowledge with their language ability.
Referring to the importance of developing the four English skills - listening, speaking, reading, and writing - as stated in the curriculum, writing appears a crucial factor that can support the process of mastering the other skills when it is taught in an integrated way (Depdiknas, 2003; Depdiknas, 2006). Writing is an important skill that involves a whole life skill (Zainuddin, 2004). As one of the four basic language skills, writing tends to play a very pivotal role in the context of teaching English as a foreign language (TEFL) in Indonesia. In this context, as mentioned in the 2006 Standard of Content, the English teaching at SMA/MA focuses on texts. It means that the students are expected to have capability in a discourse, that is, they should be able to understand and or produce the texts such as in the form of written text (Depdiknas, 2006).

Proficiency to write in English is one of the basic requirements for those who want to involve themselves in occupational or academic purposes as well as in international life (Nirwani, 2007). In any case, nowadays the students of SMA/MA might involve themselves in those proposes. That is why mastering writing in English should be provided for students as early as possible. 
The 2006 Standard of Content indicates that writing competence includes the competence in writing short functional texts, monolog texts or essays in the form of procedure, descriptive, recount, narrative, report, news item, analytical exposition, hortatory exposition, spoof, explanation, discussion, review, and public speaking. More specifically, it is described in the standard of competence. Among other things, the standard of competence for the second semester of the tenth-year students of SMA/MA in writing skill is to enable students to express a meaningful idea in short functional written texts and simple essays in the form of narrative, descriptive, and news item in daily life contexts. This standard of competence is developed into several basic competences and one of the basic competencies is that the students are able to make a descriptive text.

Related to the role of writing, Ur (1996:162) states that writing has three functions - as a means, as an end, and as a means as well as an end. As a means, writing is widely used within foreign language courses as a way for engaging with aspects of language other than the writing itself. As an end, writing is the main objective of activities. At a micro level, writing can be in the forms of word and sentence or in the forms of hand-writing or typing, while at a macro level, the emphasis is on content and organization. In this category, the writing task invites the students to express themselves using their own words. Thus it can be said that writing can be the end of the learners in expressing their ideas. As both a means and an end, writing combines original writing with the learning or practice of some other skills. In this stage, writing is integrated with the other skills such as listening, speaking, and reading.

Writing, as one of the productive skills that should be developed in instructional activities, is considered to be the most complicated problem for students. The teaching of writing in senior high schools is still hampered by a number of problems. A number of problems in writing are shown in much research. A study conducted by Kusumaningtyas (2005) showed that the students' writing skill was still poor. They did not have ability to organize ideas and sentences into coherent paragraphs. Another study was conducted by Jafaruddin (2006) aiming at identifying and evaluating the students' ability to write unified and coherent essays. The finding showed that most of the essays had poor coherence and unity. In addition, Nirwani (2007) found that the students' piece of writing was overwhelmed with a lot of errors resulted from the lack of vocabulary; besides, they did not have sufficient skill in organizing ideas into a good text. From the findings described above, it can be concluded that there are some problems found in writing teaching. Therefore, it is of paramount importance to improve the students' writing ability.

In relation to the students' difficulties in writing, Mukminatien (1991) states that the difficulties are not merely caused by the students' themselves but they can also be caused by the unvaried and uninteresting techniques of the teachers in teaching writing. These will result in the students' boredom and less motivation in learning it. Consequently, writing is not a favorite subject, not only for the students but also for the teachers. Very few of the English teachers are interested in teaching writing because the English subject needs much time to prepare and to evaluate.

In addition, Gebhard (2000:235) points out that there are three problems faced by the English as a Foreign Language (EFL) or English as Second Language (ESL) teachers in writing instructions. First, it deals with the teaching of the lessproficient students. The less-proficient students tend to use ineffective writing strategies, and the teacher is faced with showing the students how to write. Second, it deals with the students who think that they cannot write in English. Some students have negative attitudes on writing or lack confidence in themselves as the writers. They usually complain that they cannot write in English. Third, it deals with the teachers' response. The students generally do not pay attention to the teachers' comments and corrections to their written work. Consequently, the teachers should find an effective way of building students' self-confidence by which can change their negative attitude toward writing activities.

In accordance with the problems indicated above, the problems also happened to the researcher as an English teacher. He faced the same problems in English teaching in the classroom. His experience as an English teacher of the tenthyear students at Madrasah Aliyah (MA) Mambaus Sholihin Gresik shows that the students' ability in writing English is still low. It is supported by the preliminary study conducted on the $10^{\text {th }}$ and $24^{\text {th }}$ of August 2008. The average score obtained from the students' writing task was 50.5. This result is considered to be insufficient since it did not yet achieve the target of the study at the school. It must be at least 65 for minimum standard of writing success as stated in the minimum of completion criteria or Kriteria Ketuntasan Minimal (KKM) at the school. Besides, it is also 
found that there are some problems to solve. The main problem is that the students did not know how to generate and organize ideas for writing a topic.

In response to the causes of the problem, this study is focused on solving the problem related to how the students generate and organize ideas to write for the topic. They tend to be the urgent problems to solve, since in the writing process, the teachers' role is to provide chances for students to develop workable strategies for getting started to generate writing ideas and organize them (Gebhard, 2000:225). To accomplish this, the teachers are encouraged to have students work through a process of prewriting then drafting, revising, editing, and publishing (Tompkins \& Hoskisson, 1995). Prewriting stage encourages the generation of ideas (Brown, 2001:348) and it is a way of organizing students' thoughts and beginning to put the information they have (English Works Online, 2002). In addition, as indicated by Graves in Widiati \& Widayati (1997), students can produce creative and interesting texts when teachers allow their students time and opportunity. Among other things, it is for generating ideas. In fact, the generation and organization of ideas are very necessarily conducted before the students are going to write. Therefore, the researcher intends to solve the problems.

Regarding the problems to solve, the researcher proposes mind mapping with the proper model to improve the tenth-year students' ability in writing a descriptive text. Some reasons for proposing mind mapping as a strategy applied in this study because it has never been used in the writing class at the school. The researcher himself has never used it. Additionally, he believes that the strategy with the proper model developed seems to be applicable to the teaching of writing. It can hopefully overcome the students' problems especially in terms of how they generate and organize ideas to write for the topic in writing and improve their writing ability.

Mapp (2002) suggests that mind mapping is a powerful accelerated learning technique that is available to both teachers and students. Its inherent simplicity and power come from its design and rules. It is used to assist thinking, learning, and remembering. Once a student or teacher becomes competent in the use of the technique, it usually becomes their preferred way of organizing thoughts, planning, preparation and delivery of talks, making notes and communicating information to themselves and others. This technique, as a way to explore a topic beginning with a thought or word, can encourage the students to write. Once the strategy becomes familiar, it helps learners to handle any writing they face at colleges or on jobs. In terms of discovering and organizing ideas, mind mapping is a worth applying in the process of writing.

On the basis of the background of the study stated, the research problem is formulated as follows: "How can mind mapping strategy improve the tenth-year students' writing ability at MA Mambaus Sholihin Gresik?" Meanwhile, this study aims at developing mind mapping strategy to improve the tenth-year students' writing ability at MA Mambaus Sholihin Gresik.

The study centers on developing mind mapping strategy to solve the problems of generating and organizing ideas in writing a topic. Regarding the assessment, this study focuses upon the components of writing - content, organization, and grammar. Those three aspects are paramount importance to assess since they can establish the quality of the writing. Content is the substance and the essence of writing. It is the heart-beat of any great writing. To develop the paragraphs students soundly organize the specific facts and ideas, and require grammar for making sentences (Onukwugha, 2007).

Meanwhile, since the implementation of the strategy in this study is centered on improving the tenth-year students' writing ability at MA Mambaus Sholihin Gresik in the second semester of the academic year 2008/2009, the text type of writing is limited to descriptive text as provided in the 2006 Standard of Content of SMA/MA.

The study is expected to give meaningful contribution to both the students and the English teachers. It is expected that the students will use mind mapping as a strategy to generate and organize ideas to write so that they can tackle any writing situation encountered in school or job. To the English teachers, this study can hopefully solve the problem in teaching writing in terms of generating and organizing ideas to write for the topic and enable them to improve the students' skill in writing.

\section{Method}

The design of the study is collaborative classroom action research. Both the researcher and his collaborator work together in cyclic activities (Kemmis and McTaggart, 1992) - planning, implementing, observing, and reflecting on the data gained from the teaching and learning process - which runs into three cycles, each of which covers four meetings. The subjects of the 
study are the students of class X-6 of the second semester in the 2008/2009 academic year which consists of thirty-eight male students.

In implementing the action, it was decided that the researcher acted as the teacher conducting the teaching in the class, while his collaborator acted as an observer observing the activities and performance during the implementation of the action. In the data analysis, the researcher analyzed the data based on the classification. The data dealing with the students' writing achievement were analyzed by utilizing the scoring rubric adapted from Cohen (1994:328329). The student's individual score was obtained from the sum of scores from each component obtained by the student, while the mean of the students' score was obtained from the sum of the student's individual score divided by the number of the students. Besides, the students' writings were analyzed and scored by the researcher (rater 1) and his collaborator (rater 2) independently to avoid the subjectivity of the gained scores. The student's final writing score was obtained from the mean score of the student's individual score taken by rater 1 and the student's individual score taken by rater 2 . The result of the analysis was then presented quantitatively in the form of number as shown in Table 1, 3, and 5.

The data dealing with the students' involvement in the writing activities gathered through observation checklist were analyzed quantitatively based on the number of the scale checked by the observer in the observation checklist. The percentage of the students doing the activities was gained from the total scores divided by the maximum score and then multiplied by one hundred per cent. The results of the analysis were next presented quantitatively as well as qualitatively by interpreting the number of percentage gained.

In addition, the data-gathering through field notes were analyzed and then merely presented descriptively by presenting the description of the teaching and learning process. Meanwhile, the data gained from questionnaire were analyzed by scoring the items based on the weight of each option. For favorable or positively stated items, the numeric value $5,4,3,2$, and 1 were respectively assigned to the response categories beginning at the favorable end. For unfavorable or negatively stated items, the weighting was reversed. The results of scoring the items further were interpreted and presented descriptively.

The results of all the analyses, furthermore, were employed to decide whether the predetermined criteria of success were met or not. The result of this reflection was then used as the basic consideration to draw a conclusion whether the action stopped or needed improving. If the action met the criteria of success, it stopped. Otherwise, the drawbacks were identified for further revised plan and then implemented it in the next cycle.

\section{Results from Cycle I}

\section{The Students' Achievement}

Based on the Analysis on the Students' Compositions in Cycle I (Table 1), the findings show that the students' achievement in writing a descriptive text in Cycle I was not satisfactory yet. It was found that the percentage of the students achieving the score greater than or equal to 65 was only $36.11 \%$ (13 students of the class). It means that the result did not meet the first criterion of success as stated that the criterion was reached if $\geq 75 \%$ students of the class achieved the score greater than or equal to 65 of the range that lies from $0-100$.

It happened because the students still could not yet produce a good descriptive text. The fact showed that the students' essays were not complete with details yet. There were still many mistakes made by the students in their writings. The results of the writing assessment administrated showed that the students still made some mistakes in terms of content, organization, and grammar.

Most of the students' writings did not present some details information yet. The topic sentence or main ideas of their paragraphs stated somewhat unclear or inaccurate and some others stated not clear or accurate. Their writings were organized with ideas that were generally related but it did not have sentence connectors while some others loosely organized but main ideas clear, logical, but incomplete sequencing. Besides, their writings still contained grammatical mistakes. The mistakes made by the students made their writings not easy to understand.

\section{The Students' Involvement}

Based on the analysis on the data gained from the observation checklist in Cycle I as shown in Table 2 , the findings show that the students' involvement in the writing activities was categorized as fair. It was found that only $59 \%$ students (22 students of the class) were active in the writing activities. It means that the result was fail since it did not meet the second criterion of success. It was stated that the criterion was reached if the students' involvement during the 
implementation of strategy in the writing activities was categorized as good (65\%-84\% students of the class or 26-32 students did the activity).

It happened since during the teaching and learning process in the four meetings, the students faced the trend problem. Most of the students had problem related to the vocabulary items so they were still confused to generate ideas because of their limited vocabulary.

\section{Revision on the Strategy}

The revision for the following action was focused on the procedures of the implementation of the model of mind mapping. First, when the teacher assigned the students to practice making mind map, he provided one picture to each student. It was done to give a clear object (picture) the students were going to describe since in Cycle I the picture given to the students was only one picture for one group. The picture was only little picture so it was not clear to see and to describe. By giving one picture to each student, it hopefully made the students easier to find ideas. Second, the teacher clarified his explanation by describing the strange words or sentences clearly and repeatedly when some students looked confused to interest the students and to avoid miscommunication. It was done in every writing stage. Third, the teacher provided the model of the rough drafts and the guidelines individually, one model for one student and revised the guidelines to solve the students' problems related to capitalization of the first letter of the proper nouns and indentation of the paragraphs. Fourth, the teacher equipped with vocabulary guide related to the topic of the lesson as the initial language input to do the task in prewriting activity and continuously used in the following stages. The students were also provided with some dictionaries from the school library. It was aimed at helping the students to solve their problem since they got difficulties with the vocabulary. Fifth, the teacher assigned the students to do the tasks individually in every writing stage while they worked cooperatively in group. It was done to support them to be active in doing the task since they were finally hoped to produce the writings. Moreover, the students practiced writing cooperatively because the writing activities could be done in the group.

\section{Results from Cycle II}

\section{The Students' Achievement}

Based on the Analysis on the Students' Compositions in Cycle II (Table 3), it was found that the percentage of the students achieving the score greater than or equal to 65 was $52.78 \%$ (19 students of the class). This percentage was greater than those obtained from Cycle I (36.11\% or 13 students of the class). From those findings, it means that the students' achievement in writing a descriptive text in Cycle II improved enough but it did not meet the first criterion of success. It was stated that that the criterion was reached if $\geq 75 \%$ students of the class achieved the score greater than or equal to 65 of the range that lies from 0-100.

Generally the students could produce an understandable descriptive text because of their ability to write which had better content, organization, and grammar than in the previous cycle. However, there were still some mistakes made in the students' writings, though the mistakes were not as much as those they made in the previous cycle. The number of students who had made mistakes was less in this occasion. It seemed that the students who had lower of achievement in this class were the ones who did mistakes. The results of the writing assessment administrated showed that the students still made some mistakes in terms of content, organization, and grammar.

Some students' writings did not present some details information yet. The topic sentence or main ideas of their paragraphs stated fairly, clearly and accurately but some others stated somewhat unclear or inaccurate. The students' paragraphs fairly well organized and generally coherent, meanwhile some others loosely organized but main ideas clear, logical, but incomplete sequencing. Besides, their writings still contained some mistakes of grammar. However, the mistakes did not blur the clarity of meaning as the students' writings were still understandable.

\section{The Students' Involvement}

Based on the analysis on the data gained from the observation checklist in Cycle II (Table 4), it was found that $73 \%$ students (28 students) were actively involved in the writing activities. This result was greater than those gained from Cycle I (59\% students or 22 students). From those findings, it means that the students' involvement in the writing activities was categorized as good and it met the second criterion of success. It was stated that the criterion was reached if the students' involvement in the writing activities was categorized as good (65\%-84\% students of the class or 26-32 students did the activity). 
Related to the teaching and learning process in the four meetings, the researcher found the trend of the students' problems. The students still had problem related to the vocabulary items so they were still confused to generate ideas because of their limited vocabulary.

\section{Revision on the Strategy}

Some modifications for the following action had made. It was centered on the procedures of implementing the action in order to find the proper model of mind mapping applicable in the writing class. First, the teacher provided the media of the real object namely their school. It was expected that they could explore more ideas or information they got from observation. To do this, the teacher assigned the students to observe the real object before writing. Besides, the teacher still equipped the students with the vocabulary guide and provided them with some dictionaries. Second, the teacher gave maximal guidance and control in doing the prewriting and drafting activities. He continuously trained the students by activating them in developing mind mapping by giving more exercises in using drafting guidelines. By this emphasis, the students were expected to be more serious and active to do the tasks. So, in drafting activity, the activity referred to the prewriting activity and their drafts were more suitable with their ideas in the map they had made. Third, the teacher provided the students some more chances to do proofreading, peer editing, and sharing their writings in conferences as well as much control by monitoring the students' activities on the task and walking around the class using time effectively. So, they were expected to be more actively involved in those activities.

\section{Results from Cycle III}

\section{The Students' Achievement}

Based on the Analysis on the Students' Compositions in Cycle III (Table 5), it was found that the percentage of the students achieving the score greater than or equal to 65 was $82.86 \%$ (29 students of the class). This percentage was greater than those obtained from Cycle II (52.78\% or 19 students of the class). From those findings, it means that the students' achievement in writing a descriptive text in Cycle III improved and it met the first criterion of success. It was stated that that the criterion was reached if $\geq 75 \%$ students of the class achieved the score greater than or equal to 65 of the range that lies from 0 100.
Even though the students' achievement in writing improved, it was still found the certain types of mistakes made by the students in their writing. The number of the mistakes had begun reducing. It seemed that the students who did some mistakes were those who were categorized as the students of the lower of English. Most of the students' writings presented more details information. Most of the topic sentences or main ideas of their paragraphs stated fairly, clearly and accurately. Most of the students' paragraphs fairly well organized and generally coherent and their writings still contained some grammatical mistakes. Even though some students could not yet revise their inappropriate sentences, their writings had already improved. The students could express their ideas dealing with describing the place 'My School'. Their descriptive texts were already understandable and readable since they had good content and organization.

\section{The Students' Involvement}

Based on the result of observation from Cycle III (Table 6), it was found that $90 \%$ students (34 students) were actively involved in the writing activities. This result was greater than those gained from Cycle II $(73 \%$ students or 28 students). It means that the students' involvement in the writing activities was categorized as very good and it met the criterion of success. It was stated that the criterion was reached if the students' involvement in the writing activities was categorized as good (65\%$84 \%$ students or $26-32$ students did the activity).

\section{Discussions}

\section{The Procedures Employed in the Implementation of Mind Mapping}

Based on the findings of the study, the implementation of mind mapping can improve the students' ability in writing a descriptive text. Although all students have not achieved the maximum results, most of their writing abilities have improved as shown in the results of the assessment in each cycle (Table 1, 3, and 5).

With regard to the above description, it seems that the students are able to communicate by using written language in which they do all of the activities provided by the teacher during the process of the action cycles. Those activities are related to the procedures employed in writing a descriptive text that may improve their writing ability. The proper model of mind mapping developed by the teacher for writing activities involves the application of the writing process prewriting, drafting, revising, editing, and 
publishing (Tompkins \& Hoskisson, 1995). The application of the writing process is as follows.

Prewriting activities focused on introducing mind mapping to the students by giving them a model of implementing mind mapping as a strategy in generating and organizing ideas. Prewriting is a preparation to write and the getting-ready-towrite stage which is like a warming-up for the athletes (Tompkins \& Hoskisson, 1995:211).

The teacher introduced mind mapping to the students by giving them a model of implementing mind mapping as a strategy in generating and organizing ideas. (1) The teacher wrote down the object (topic or key word) in a circle. (2) He elicited the students' ideas for the possible supporting ideas by drawing rays from the circle, one ray for one supporting idea. The students, depending on what they have been studying and on their prior knowledge, offered words related to the key concept word (Vacca \& Vacca, 1999). These are recorded by the teacher on the blackboard. (3) He then guided them to develop each supporting idea by adding the branches to each ray and asking the students to complete each of them with more detailed ideas since it frees the students to think more creatively, to associate ideas more easily, and to organize and analyze information visually (Teo, 2003). (4) He equipped the mind mapping with some missing words related to the topic as the initial language input reinforced with a short drill session.

Drafting activities focused on providing the students chances to start writing based on mapped idea they had made in the previous meeting. The students were assigned to write rough draft as their first draft. Drafting is a stage designed to allow the writers to put their ideas on paper without worrying about mechanics or neatness (Roe et al., 1995).

To guide the students how to do drafting, the teacher guided them to check a model of rough draft step-by-step by using drafting guidelines. (1) The students were assigned to check whether the essay contained text organization (identification) or not. (2) They were assigned to check whether the essay contained text organization (descriptions) - describing physical features, personality, parts, quality, and characteristics - or not. (3) They were assigned to check whether the essay contained language features (the use of simple present form, adjectives, verb be, have, look, etc.) or not.

Revising activities focused on providing the students chances for revising the first draft they had made in the drafting stage with emphasis on the content and organization rather than on the mechanics. Revising is to make the writing clearer and more interesting to the readers (Glencoe, 2001). In this stage, students rethink and rewrite the first draft, forming the second draft.

Before coming to the real revising activity, the students were guided to revise a model of rough draft step-by-step. (1) The students were assigned to check whether each paragraph had topic sentence or not. (2) They were assigned to check whether the topic sentence of each paragraph was clear or not. (3) They were assigned to check whether all the supporting sentences of each paragraph referred to the topic sentence or not. (4) They were assigned to check whether all the sentences of each paragraph were well organized or not. (5) They were assigned to check whether the paragraphs used sentence connectors or not. (6) They were assigned to check whether the first sentence of each paragraph is indented or not.

Editing activities focused on providing the students chances to edit the drafts, and proofread the drafts for accuracy and correctness in spelling, punctuation, capitalization and grammar. Editing is putting the piece of writing into its final form. It is the process in which the students begin to look at correctness (Stone, 1990). Tompkins \& Hoskisson (1995) assert that the editing stage primarily focuses on the content of students' writing.

Before the students did real editing process, the students were guided to edit a model of rough draft step-by-step through editing guidelines. The students were assigned to answer the questions provided step by step. (1) The students were asked to check the draft whether each paragraph used the correct tense or not. (2) They were asked to check whether all the subjects and verbs are agreed or not. (3) They were asked to check whether all the sentences used correct word order or not. (4) They were asked to check whether the sentences used correct plural form or not. (5) They were asked to check whether the first letter of each sentence is capitalized or not. (6) They were asked to check whether the first letter of the proper nouns is also capitalized or not. (7) They were asked to check whether each sentence used punctuation correctly or not. (8) They were asked to check whether all words were spelled correctly or not.

Publishing activities focused on providing the students chances to share the final product with the other students. In publishing stage, students bring their compositions life by publishing them or sharing them orally with an appropriate 
audience (Tompkins \& Hoskisson, 1995). It means that they shared their writings with real audiences of classmates, other students, parents and community.

Other aspects considered that had given a significant contribution to the students' improvement during the process of the teaching and learning writing paragraphs particularly when implemented mind mapping were: (1) clear instruction and explanation, (2) maximal guidance and control, (3) the need of media related to the topic (pictures and the real object),

(4) the need of vocabulary guide and dictionary,

(5) the more exercises of using guidelines, and

(6) the way of grouping

\section{The Improvement of the Students' Writing Ability}

The implementation of mind mapping with the proper model developed can improve the students' ability in writing a descriptive text. The improvement can be examined from the improvement of the students' achievement in writing a descriptive text and the students' involvement in the writing activities during the implementation of mind mapping in the teaching and learning process.

The students' achievement in writing a descriptive text improved is shown from the improvement of the percentage of the students achieving the score greater than or equal to 65 in Cycle I, II, and III as shown in Figure 1.

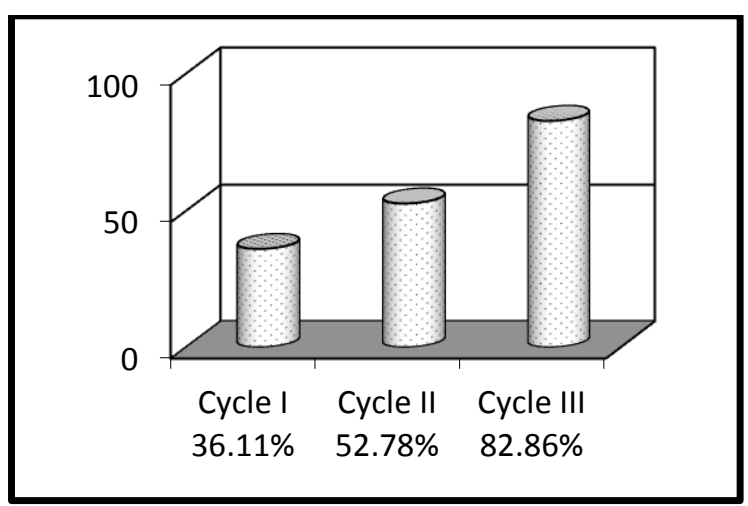

Figure 1 The Improvement of the Percentage of the Students Achieving the Score $\geq 65$

The Figure 1 shows that the percentage of the students achieving the score greater than or equal to 65 in Cycle I was 36.11\% (13 students of the class). In Cycle II, the percentage of the students achieving the score greater than or equal to 65 increased into $52.78 \%$ (19 students of the class). Meanwhile, the percentage of the students achieving the score greater than or equal to 65 increased into $82.86 \%$ (29 students of the class). This was a slight improvement.

Dealing with the students' involvement in the writing activities during the implementation of mind mapping in the teaching and learning process, it is shown from the percentage of the students' involvement in the writing activities in every cycle. The improvement of the students' involvement in the writing activities in Cycle I, II, and III is shown in Figure 2.

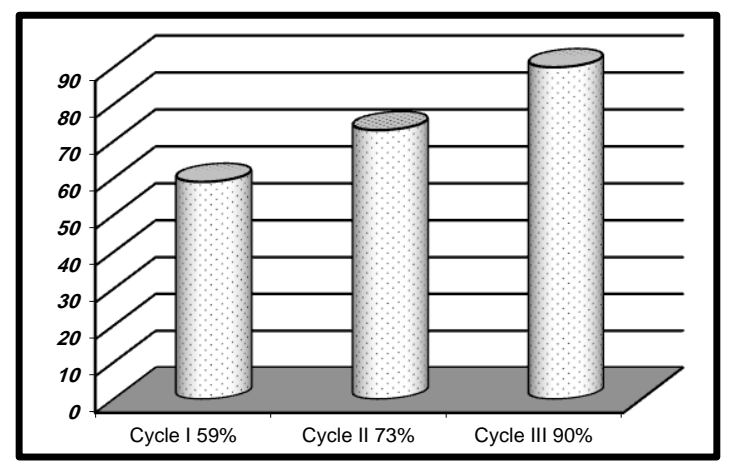

Figure 2 The Improvement of the Students' Involvement in the Writing Activities

The Figure 2 shows that in Cycle I, some students did not implement all activities seriously, only $59 \%$ students (22 students) involved in the writing activities. In Cycle II, the students involved in the writing activities increased into $73 \%$ students (28 students). Meanwhile, in Cycle III, the students involved in the writing activities increased to $90 \%$ students (34 students). They were actively involved in the writing activities.

\section{Conclusions}

By implementing mind mapping with the proper model developed, the students' ability in writing a descriptive text improves. It is indicated by the improvements: (1) the improvement of the percentage of the students achieving the score greater than or equal to 65 in Cycle I, II and III (Figure 1), and (2) the improvement of the percentage of the students' involvement in the writing activities during the implementation of mind mapping in the teaching and learning process in Cycle I, II, and III (Figure 2). The success of this study is in Cycle III. So, it needs long time to succeed in this study.

The improvement of the students' ability in writing a descriptive text can be reached but it should follow the procedures of the proper model of mind mapping as follows: (1) tell the students about the objectives of the lesson, (2) show the picture that will be described and ask the students to observe it, (3) write the object 
(topic or key word) in a circle and elicit the students' ideas for the possible supporting ideas by drawing rays from the circle, one ray for one supporting idea, (4) guide the students to develop each supporting idea by adding the branches to each ray, (5) guide the students to make sentences to develop each supporting idea with its details into a paragraph based on the mapped ideas, (6) distribute a model of descriptive text related to the topic discussed, and ask the students to read and understand it, (7) arrange the students to become groups of four, (8) distribute the other different pictures related to the topic discussed to each student or (in other ways) assign the students to observe the real object using students' worksheet, (9) distribute larger papers (A4) to the students to do the task, equip them with vocabulary guides and dictionaries, and then train them by reinforcing with a short drill session, (10) ask the students to generate and organize ideas through mind mapping based on the pictures or the objects observed, (11) guide the students to do drafting using drafting guidelines, (12) assign the students to write the first drafts based on their mapped ideas, (13) ask the students to place a greater emphasis on content and organization than on mechanics, (14) guide the students to revise the draft using revising guidelines, (15) ask the students to revise their own drafts using revising guidelines and to use their mapped ideas to develop the content of their first draft, (16) assign the students to proofread their friends' rough drafts and to share them by exchanging the drafts with one another, (17) ask the students to make substantive changes between first and second drafts, (18) guide the students to do editing using the editing guidelines, (19) ask the students to edit their own drafts using editing guidelines and to use their mapped ideas to check/revise the content, organization, grammar, and mechanics of their second draft, (20) assign the students to proofread again by exchanging the second drafts with one another, (21) assign the students to share their final writings by reading them aloud to the whole class, and (22) ask the students to submit their final writings to assess.

Some suggestions are provided to follow up the findings of this study. First, since teaching writing is the most complicated aspect in language teaching, the English teachers are recommended to employ the proper model procedure of mind mapping as one of the alternative strategies in their writing class. However, the procedures proposed need to agree with the students' conditions in their class. They should develop their way of teaching related to the procedures of how to implement mind mapping for the more appropriate in their writing class. To do so, they have better to develop it through English teacher trainings and discussions. Second, the principal as a policy maker is suggested to provide special lesson time for students to practice the continuous English writing. Third, future researchers are recommended to conduct such kinds of research concerned with the implementation of mind mapping in English teaching for the other skills - listening, speaking, and reading - and for the other levels such as elementary school, junior high school, and university by considering the strength of mind mapping as a strategy in English teaching

Table 1. The Students' Final Writing Score in Cycle I

\begin{tabular}{llllc}
\hline No & Students & SIS-1 & SIS-2 & $\begin{array}{c}\text { Student's Final } \\
\text { Writing Score }\end{array}$ \\
\hline 1 & AK & 54,0 & 61,5 & 57,8 \\
\hline 2 & AA & 46,0 & 46,0 & 46,0 \\
\hline 3 & AQ & 69,5 & 77,0 & 73,3 \\
\hline 4 & AAN & 77,0 & 69,5 & 73,3 \\
\hline 5 & AAS & 77,0 & 69,5 & 73,3 \\
\hline 6 & AD & 31,0 & 54,0 & 42,5 \\
\hline 7 & ASM & 54,0 & 69,5 & 61,8 \\
\hline 8 & AZ & 38,5 & 54,0 & 46,3 \\
\hline 9 & AAA & 69,5 & 77,0 & 73,3 \\
\hline 10 & AN & 61,5 & 69,5 & 65,5 \\
\hline 11 & CA & 46,0 & 38,5 & 42,3 \\
\hline 12 & HA & 46,5 & 46,0 & 46,3 \\
\hline 13 & IF & 69,5 & 69,5 & 69,5 \\
\hline 14 & IT & 31,0 & 38,5 & 34,8 \\
$*$
\end{tabular}




\begin{tabular}{lllll}
15 & MH & 69,5 & 77,0 & 73,3 \\
\hline 16 & MIZ & 69,5 & 77,0 & 73,3 \\
\hline 17 & ML & 38,5 & 31,0 & 34,8 \\
\hline 18 & MR & 69,0 & 77,0 & 73,0 \\
\hline 19 & MAA & 77,0 & 69,0 & 73,0 \\
\hline 20 & MSD & 53,5 & 38,5 & 46,0 \\
\hline 21 & MSY & 38,5 & 46,0 & 42,3 \\
\hline 22 & MA & 54,0 & 46,0 & 50,0 \\
\hline 23 & MF & 53,5 & 54,0 & 53,8 \\
\hline 24 & MM & 69,5 & 69,5 & 69,5 \\
\hline 25 & MWW & 77,0 & 69,5 & 73,3 \\
\hline 26 & MYI & 38,5 & 31,0 & 34,8 \\
\hline 27 & MU & 61,5 & 61,5 & 61,5 \\
\hline 28 & MUH & 46,0 & 38,5 & 42,3 \\
\hline 29 & MD & & & \\
\hline 30 & NAS & 61,5 & 54,0 & 57,8 \\
\hline 31 & NKH & 69,5 & 61,5 & 65,5 \\
\hline 32 & NW & & & \\
\hline 33 & NM & 46,0 & 38,5 & 42,3 \\
\hline 34 & SBS & 38,5 & 61,5 & 50,0 \\
\hline 35 & SW & 61,5 & 61,5 & 61,5 \\
\hline 36 & SR & 46,0 & 46,5 & 46,3 \\
\hline 37 & TA & 61,5 & 54,0 & 57,8 \\
\hline 38 & UA & 38,5 & 46,0 & 42,3 \\
\hline$N$ & SIS-1 & 513
\end{tabular}

Note: $\quad$ SIS-1 : Student's Individual Score taken by Rater 1

SIS-2 : Student's Individual Score taken by Rater 2

In Cycle I, the percentage of the students achieving the score greater than or equal to 65 was $\mathbf{3 6 . 1 1 \%}$ (13 students) *

Table 2. The Result of Observation from Cycle I

\begin{tabular}{|c|c|c|c|c|c|c|c|c|c|}
\hline \multirow{2}{*}{ Meeting } & \multirow{2}{*}{$\begin{array}{l}\text { Writing } \\
\text { Stage }\end{array}$} & \multirow{2}{*}{$\begin{array}{l}\text { Items of Description } \\
\text { of Students' Activities }\end{array}$} & \multicolumn{5}{|c|}{ Scale } & \multirow{2}{*}{ Score } & \multirow{2}{*}{ Percentage } \\
\hline & & & 1 & 2 & 3 & 4 & 5 & & \\
\hline \multirow{4}{*}{1} & \multirow{4}{*}{ Prewriting } & 1 & & & $\sqrt{ }$ & & & 3 & \\
\hline & & 2 & & & $\sqrt{ }$ & & & 3 & \\
\hline & & 3 & & $\sqrt{ }$ & & & & 2 & \\
\hline & & 4 & & & $\sqrt{ }$ & & & 3 & \\
\hline & & \multicolumn{6}{|l|}{ Total 1} & 11 & $55 \%$ (21 students) \\
\hline \multirow{5}{*}{2} & \multirow{5}{*}{ Drafting } & 5 & & & $\sqrt{ }$ & & & 3 & \\
\hline & & 6 & & & & $\sqrt{ }$ & & 4 & \\
\hline & & 7 & & & $\sqrt{ }$ & & & 3 & \\
\hline & & 8 & & & $\sqrt{ }$ & & & 3 & \\
\hline & & 9 & & $\sqrt{ }$ & & & & 2 & \\
\hline & & Total 2 & & & & & & 15 & $60 \%$ (23 students) \\
\hline \multirow{4}{*}{3} & \multirow{4}{*}{ Revising } & 10 & & $\sqrt{ }$ & & & & 2 & \\
\hline & & 11 & & & $\sqrt{ }$ & & & 3 & \\
\hline & & 12 & & & $\sqrt{ }$ & & & 3 & \\
\hline & & 13 & & & $\sqrt{ }$ & & & 3 & \\
\hline \multicolumn{8}{|c|}{ Total 3} & 11 & $55 \%$ (21 students) \\
\hline
\end{tabular}




\begin{tabular}{|c|c|c|c|c|c|c|c|}
\hline \multirow{5}{*}{4} & \multirow{4}{*}{ Editing } & 14 & & $\sqrt{ }$ & & 3 & \\
\hline & & 15 & $\sqrt{ }$ & & & 2 & \\
\hline & & 16 & & $\sqrt{ }$ & & 3 & \\
\hline & & 17 & & & $\sqrt{ }$ & 5 & \\
\hline & Publishing & 18 & & $\sqrt{ }$ & & 3 & \\
\hline Total & & & & & & 16 & $64 \%$ (24 students) \\
\hline Total & $2+3+4)$ & & & & & 53 & $59 \%$ (22 students) \\
\hline
\end{tabular}

* In cycle I, the percentage of the students doing the activities is $\mathbf{5 9 \%}$ (22 students) categorized as fair (fail).

Table 3. The Students' Final Writing Score in Cycle II

\begin{tabular}{|c|c|c|c|c|}
\hline No & Students & SIS-1 & SIS-2 & $\begin{array}{l}\text { Student's Final } \\
\text { Writing Score }\end{array}$ \\
\hline 1 & $\mathrm{AK}$ & 69,0 & 61,5 & 65,3 \\
\hline 2 & $\mathrm{AA}$ & 61,5 & 46,0 & 53,8 \\
\hline 3 & $\mathrm{AQ}$ & 46,0 & 61,5 & 53,8 \\
\hline 4 & AAN & 77,0 & 84,5 & 80,8 \\
\hline 5 & AAS & 77,0 & 77,0 & 77,0 \\
\hline 6 & $\mathrm{AD}$ & 69,0 & 61,5 & 65,3 \\
\hline 7 & ASM & 46,0 & 61,5 & 53,8 \\
\hline 8 & $\mathrm{AZ}$ & 69,0 & 61,5 & 65,3 \\
\hline 9 & AAA & 46,0 & 61,5 & 53,8 \\
\hline 10 & AN & 61,5 & 46,0 & 53,8 \\
\hline 11 & $\mathrm{CA}$ & 77,0 & 69,0 & 73,0 \\
\hline 12 & HA & 54,0 & 54,0 & 54,0 \\
\hline 13 & IF & 69,0 & 54,0 & 61,5 \\
\hline 14 & IT & 54,0 & 61,5 & 57,8 \\
\hline 15 & $\mathrm{MH}$ & 84,5 & 77,0 & 80,8 \\
\hline 16 & MIZ & 77,0 & 69,0 & 73,0 \\
\hline 17 & ML & 77,0 & 77,0 & 77,0 \\
\hline 18 & MR & 69,0 & 61,5 & 65,3 \\
\hline 19 & MAA & 77,0 & 84,5 & 80,8 \\
\hline 20 & MSD & 46,0 & 54,0 & 50,0 \\
\hline 21 & MSY & 77,0 & 77,0 & 77,0 \\
\hline 22 & MA & 46,0 & 61,5 & 53,8 \\
\hline 23 & $\mathrm{MF}$ & 77,0 & 77,0 & 77,0 \\
\hline 24 & MM & 77,0 & 69,5 & 73,3 \\
\hline 25 & MWW & 77,0 & 77,0 & 77,0 \\
\hline 26 & MYI & 54,0 & 46,0 & 50,0 \\
\hline 27 & MU & 54,0 & 61,5 & 57,8 \\
\hline 28 & MUH & 69,5 & 77,0 & 73,3 \\
\hline 29 & MD & 46,0 & 46,0 & 46,0 \\
\hline 30 & NAS & 77,0 & 77,0 & 77,0 \\
\hline 31 & $\mathrm{NKH}$ & & & \\
\hline 32 & NW & 46,0 & 54,0 & 50,0 \\
\hline 33 & NM & 77,0 & 69,0 & 73,0 \\
\hline 34 & SBS & & & \\
\hline 35 & SW & 61,5 & 54,0 & 57,8 \\
\hline 36 & SR & 46,0 & 54,0 & 50,0 \\
\hline 37 & $\mathrm{TA}$ & 77,0 & 69,0 & 73,0 \\
\hline 38 & UA & 54,0 & 46,0 & 50,0 \\
\hline
\end{tabular}


Note: SIS-1 : Student's Individual Score taken by Rater 1

SIS-2 : Student's Individual Score taken by Rater 2

In Cycle II, the percentage of the students achieving the score greater than or equal to 65 was $\mathbf{5 2 . 7 8 \%}$

(19 students) *

Table 4. The Result of Observation from Cycle II

\begin{tabular}{|c|c|c|c|c|c|c|c|c|c|}
\hline \multirow{2}{*}{ Meeting } & \multirow{2}{*}{$\begin{array}{l}\text { Writing } \\
\text { Stage }\end{array}$} & \multirow{2}{*}{$\begin{array}{l}\text { Items of Description } \\
\text { of Students' Activities }\end{array}$} & \multicolumn{5}{|c|}{ Scale } & \multirow{2}{*}{ Score } & \multirow{2}{*}{ Percentage } \\
\hline & & & 1 & 2 & 3 & 4 & 5 & & \\
\hline \multirow{4}{*}{1} & \multirow{4}{*}{ Prewriting } & 1 & & & & $\sqrt{ }$ & & 4 & \\
\hline & & 2 & & & & $\sqrt{ }$ & & 4 & \\
\hline & & 3 & & & $\sqrt{ }$ & & & 3 & \\
\hline & & 4 & & & & $\sqrt{ }$ & & 4 & \\
\hline & & \multicolumn{6}{|l|}{ Total 1} & 15 & $75 \%$ (29 students) \\
\hline \multirow{5}{*}{2} & \multirow{5}{*}{ Drafting } & 5 & & & & $\sqrt{ }$ & & 4 & \\
\hline & & 6 & & & & $\sqrt{ }$ & & 4 & \\
\hline & & 7 & & & $\sqrt{ }$ & & & 3 & \\
\hline & & 8 & & & & $\sqrt{ }$ & & 4 & \\
\hline & & 9 & & & $\sqrt{ }$ & & & 3 & \\
\hline & & Total 2 & & & & & & 18 & $72 \%$ (27 students) \\
\hline \multirow{4}{*}{3} & \multirow{4}{*}{ Revising } & 10 & & & $\sqrt{ }$ & & & 3 & \\
\hline & & 11 & & & & $\sqrt{ }$ & & 4 & \\
\hline & & 12 & & & $\sqrt{ }$ & & & 3 & \\
\hline & & 13 & & & & $\sqrt{ }$ & & 4 & \\
\hline \multicolumn{8}{|c|}{ Total 3} & 14 & $70 \%$ (27 students) \\
\hline \multirow{5}{*}{4} & \multirow{4}{*}{ Editing } & 14 & & & $\sqrt{ }$ & & & 3 & \\
\hline & & 15 & & & $\sqrt{ }$ & & & 3 & \\
\hline & & 16 & & & & $\sqrt{ }$ & & 4 & \\
\hline & & 17 & & & & & $\sqrt{ }$ & 5 & \\
\hline & Publishing & 18 & & & & $\sqrt{ }$ & & 4 & \\
\hline \multicolumn{8}{|l|}{ Total 4} & 19 & $76 \%$ (29 students) \\
\hline \multicolumn{8}{|c|}{ Total $(1+2+3+4)$} & 66 & $73 \%$ (28 students) \\
\hline
\end{tabular}

* In cycle II, the percentage of the students doing the activities is $\mathbf{7 3 \%}$ (28 students) categorized as good (succeed).

Table 5. The Students' Final Writing Score in Cycle III

\begin{tabular}{|c|c|c|c|c|}
\hline No & Students & SIS-1 & SIS-2 & $\begin{array}{l}\text { Student's Final } \\
\text { Writing Score }\end{array}$ \\
\hline 1 & $\mathrm{AK}$ & 69,0 & 77,0 & 73,0 \\
\hline 2 & AA & 61,5 & 61,5 & 61,5 \\
\hline 3 & $\mathrm{AQ}$ & 85,0 & 77,0 & 81,0 \\
\hline 4 & AAN & 92,5 & 85,0 & 88,8 \\
\hline 5 & AAS & 85,0 & 77,0 & 81,0 \\
\hline 6 & $\mathrm{AD}$ & 69,5 & 69,5 & 69,5 \\
\hline 7 & ASM & 61,5 & 69,5 & 65,5 \\
\hline 8 & $\mathrm{AZ}$ & 69,5 & 77,0 & 73,3 \\
\hline 9 & AAA & 85,0 & 69,0 & 77,0 \\
\hline 10 & AN & & & \\
\hline
\end{tabular}




\begin{tabular}{|c|c|c|c|c|}
\hline 11 & $\mathrm{CA}$ & 77,0 & 77,0 & 77,0 \\
\hline 12 & HA & 77,0 & 69,0 & 73,0 \\
\hline 13 & IF & 61,5 & 77,0 & 69,3 \\
\hline 14 & IT & 69,0 & 61,5 & 65,3 \\
\hline 15 & $\mathrm{MH}$ & 85,0 & 92,5 & 88,8 \\
\hline 16 & MIZ & 69,5 & 77,0 & 73,3 \\
\hline 17 & ML & 77,0 & 77,0 & 77,0 \\
\hline 18 & MR & 69,5 & 61,5 & 65,5 \\
\hline 19 & MAA & 85,0 & 85,0 & 85,0 \\
\hline 20 & MSD & 54,0 & 61,5 & 57,8 \\
\hline 21 & MSY & 85,0 & 77,0 & 81,0 \\
\hline 22 & MA & 69,5 & 61,5 & 65,5 \\
\hline 23 & MF & & & \\
\hline 24 & MM & 77,0 & 77,0 & 77,0 \\
\hline 25 & MWW & 77,0 & 77,0 & 77,0 \\
\hline 26 & MYI & 61,5 & 61,5 & 61,5 \\
\hline 27 & MU & 69,5 & 69,0 & 69,3 \\
\hline 28 & MUH & 85,0 & 77,0 & 81,0 \\
\hline 29 & MD & 61,5 & 61,5 & 61,5 \\
\hline 30 & NAS & 85,0 & 77,0 & 81,0 \\
\hline 31 & $\mathrm{NKH}$ & & & \\
\hline 32 & NW & 61,5 & 54,0 & 57,8 \\
\hline 33 & NM & 69,5 & 77,0 & 73,3 \\
\hline 34 & SBS & 54,0 & 61,5 & 57,8 \\
\hline 35 & SW & 69,5 & 69,5 & 69,5 \\
\hline 36 & SR & 61,5 & 69,5 & 65,5 \\
\hline 37 & $\mathrm{TA}$ & 69,5 & 69,0 & 69,3 \\
\hline 38 & UA & 69,5 & 61,5 & 65,5 \\
\hline
\end{tabular}

Note: SIS-1 : Student's Individual Score taken by Rater 1

SIS-2 : Student's Individual Score taken by Rater 2

In Cycle III, the percentage of the students achieving the score greater than or equal to 65 was $\mathbf{8 2 . 8 6 \%}$ (29 students) *

Table 6. The Result of Observation from Cycle III

\begin{tabular}{|c|c|c|c|c|c|c|c|c|c|}
\hline \multirow{2}{*}{ Meeting } & \multirow{2}{*}{$\begin{array}{l}\text { Writing } \\
\text { Stage }\end{array}$} & \multirow{2}{*}{$\begin{array}{l}\text { Items of Description } \\
\text { of Students' Activities }\end{array}$} & \multicolumn{5}{|c|}{ Scale } & \multirow{2}{*}{ Score } & \multirow{2}{*}{ Percentage } \\
\hline & & & 1 & 2 & 3 & 4 & 5 & & \\
\hline \multirow{4}{*}{1} & \multirow{4}{*}{ Prewriting } & 1 & & & & $\sqrt{ }$ & & 4 & \\
\hline & & 2 & & & & & $\sqrt{ }$ & 5 & \\
\hline & & 3 & & & & $\sqrt{ }$ & & 4 & \\
\hline & & 4 & & & & & $\sqrt{ }$ & 5 & \\
\hline & & \multicolumn{6}{|l|}{ Total 1} & 18 & $90 \%$ (34 students) \\
\hline \multirow{5}{*}{2} & \multirow{5}{*}{ Drafting } & 5 & & & & & $\sqrt{ }$ & 5 & \\
\hline & & 6 & & & & & $\sqrt{ }$ & 5 & \\
\hline & & 7 & & & & $\sqrt{ }$ & & 4 & \\
\hline & & 8 & & & & $\sqrt{ }$ & & 4 & \\
\hline & & 9 & & & & $\sqrt{ }$ & & 4 & \\
\hline & & Total 2 & & & & & & 22 & $88 \%$ (33 students) \\
\hline \multirow{2}{*}{3} & \multirow{2}{*}{ Revising } & 10 & & & & $\sqrt{ }$ & & 4 & \\
\hline & & 11 & & & & & $\sqrt{ }$ & 5 & \\
\hline
\end{tabular}




\begin{tabular}{|c|c|c|c|c|c|c|}
\hline & & 12 & $\sqrt{ }$ & & 4 & \\
\hline & & 13 & & $\sqrt{ }$ & 5 & \\
\hline & & & & & 18 & $90 \%$ (34 students) \\
\hline & & 14 & $\sqrt{ }$ & & 4 & \\
\hline & Fditing & 15 & $\sqrt{ }$ & & 4 & \\
\hline 4 & Earting & 16 & & $\sqrt{ }$ & 5 & \\
\hline & & 17 & & $\sqrt{ }$ & 5 & \\
\hline & Publishing & 18 & & $\sqrt{ }$ & 5 & \\
\hline Total & & & & & 23 & $90 \%$ (35 students) \\
\hline Total & $2+3+4)$ & & & & 81 & $90 \%$ (34 students) \\
\hline
\end{tabular}

* In cycle III, the percentage of the students doing the activities is $\mathbf{9 0 \%}$ (34 students) categorized as very good (succeed).

\section{REFERENCES}

Brown, H.D. 2001. Teaching by Principles: An Interactive Approach to Language Pedagogy (2 ${ }^{\text {nd }}$ ed.). New York: Addison Wesley Longman, Inc.

Cohen, A. D. 1994. Assessing Language Ability in the Classroom, $2^{\text {nd }}$ ed. Boston: Heinle and Heinle Publishers.

Departemen Pendidikan Nasional. 2003. Kurikulum Bahasa Inggris 2004 Sekolah Menengah Atas Madrasah Aliyah. Jakarta: Direktorat Jenderal Dikdasmen, Derektorat Pendidikan Menengah Umum.

Departemen Pendidikan Nasional. 2006. Peraturan Menteri Pendidikan Nasional No. 22. Jakarta: Direktorat Pendidikan Dasar dan Menengah.

Gebhard, J. G. 2000. Teaching English as a Foreign or Second Language: A Teacher Self-Development and Methodology Guide. Ann Arbor: The University of Michigan Press.

Glencoe. 2001. Writer's Choice: Grammar and Composition Grade 6. New York: McGraw-Hill Companies.

Jafaruddin. 2006. Improving Students' Ability in Writing Recounts by Using Picture Series in Outlining. Malang: Unpublished Thesis. State University of Malang.

Kemmis, S. \& McTaggart, R. 1992. The Action Research Planner, $3^{\text {rd }}$ ed. Victoria: Deakin University Press.

Kusumaningtyas, D. N. 2005. Improving the Second-Year Students' Skills in Writing Paragraphs through Segment-Chain Activities at SMA Negeri Kunir. Malang: Unpublished Thesis. State University of Malang.

Mapp, B. 2002. What is Mind Mapping? (Online). URL: http://www.teachingexpertise.com/articles. (Accessed 2008, April 04 ${ }^{\text {th }}$ ).

Mukminatien, N. 1991. Making a Writing Class Interesting. TEFLIN Journal: An EFL Journal in Indonesia, Volume IV Number 2, October 1991.

Nirwani, S. 2007. Applying Autonomous Writing Instruction Model to Improve the Second Year Students' Writing Skill of SMAN 7 Malang. Malang: Unpublished Thesis. State University of Malang.

Onukwugha, U. 2007. The Four Cardinal Points of Any Good Writing: Expression, Content, Organization \& Technical Accuracy. Ezine Articles.com. 28 Sep 2008: http://ezinearticles.com/?The-Four-CardinalPoints-of-Any-Good-Writing:- (Accessed 2008, September 29th). 
Rachmadie, C. K. 1995. The Effect of the Use of Still Pictures for Beginners Students in Learning Communicative English. Jurnal: Berkala Pendidikan Bahasa dan Seni, Th. I, No. 1, Juni 1995.

Roe, B. D., Stoodt, B. D. \& Burns, P. C. 1995. Secondary School Reading instruction: The Content Areas, $5^{\text {th }}$ ed. Boston: Houghton Mifflin Company.

Stone, J. M. 1990. Cooperative Learning and Language Arts: A Multi-Structural Approach. California: Resources for Teachers.

Teo, N. 2003. A Handbook for Science Teachers in Primary Schools. Singapore: Federal Publications.

Tompkins, G. E. \& Hoskisson, K. 1995. Language Arts: Content and Teaching Strategies. New York: Macmillan Publishing Company.

Ur, P. 1996. A Course in Language Teaching: Practice and Theory. Cambridge: Cambridge University Press.

Vacca, R. T. \& Vacca, J. A. L. 1999. Content Area Reading: Literacy and Learning across the Curriculum, $6^{\text {th }} \mathrm{ed}$. Boston: Addison-Weley Educational Publishers Inc.

Widiati, U. \& Widayati, S. 1997. Out of a Writing Conference: Speaking-Writing Connection. TEFLIN Journal: An EFL Journal in Indonesia, Volume VIII Number 1, August 1997.

Zainuddin, M. 2004. The Effect of Giving Feedback to Students' Writing. TEFLIN Journal: An EFL Journal in Indonesia, Volume 15 Number 2, August 2004.

2002. English Works Online: Pre-writing Strategies. (Online). URL: http://depts.gallaudet.edu/englishwor. (Accessed 2008, April 04th).. 